\title{
Use of linear features by the common vampire bat (Desmodus rotundus) in a tropical cattle-ranching landscape
}

\author{
Rafael Ávila-Flores ${ }^{1 *}$, Ana Lucía Bolaina-Badal ${ }^{1}$, Adriana Gallegos-Ruiz ${ }^{1}$ and Wendy S. Sánchez-Gómez ${ }^{1}$ \\ ${ }^{1}$ División Académica de Ciencias Biológicas, Universidad Juárez Autónoma de Tabasco,. Carretera Villahermosa-Cárdenas km 0.5 \\ S/N, CP. 86150, Villahermosa. Tabasco, México. Email: rafaelavilaf@yahoo.com.mx (RAF), bolaina badal@hotmail.com (ALBB), \\ adrianagar21@hotmail.com (AGR), wensanchez.go@gmail.com (WSSG) \\ *Corresponding author
}

\begin{abstract}
Linear landscape features are used by many species of insectivorous bats as flight routes and foraging zones, as well as for providing protection against environmental factors and predation. However, very little is known about the role that these landscape features play for noninsectivorous species. In this study, we evaluated the use of linear features by the common vampire bat (Desmodus rotundus) in a cattle-ranching landscape in the state of Tabasco, Mexico. We selected 24 sampling sites in 2014 and 24 independent sites in 2016 to 2017 , all adjacent to three types of linear landscape features: forest edges, live fences and streams. We monitored each site for two non-consecutive nights between February and April 2014, and every two months from February 2016 to June 2017. We placed 24 m (2014) or 12 m (2016 to 2017 ) of mist nets perpendicular to the linear feature from its edge. We recorded the height and distance from the edge for each individual captured. In total we captured 50 D. rotundus individuals in 2014 and 58 in 2016 to 2017. The average flight height was $77 \mathrm{~cm}$ for the 2014 data and $69 \mathrm{~cm}$ for 2016 to 2017. According to our results, the most used linear features were forest edges, followed by live fences and streams. Overall, $52 \%$ of the 2014 captures and $62 \%$ of the 2016 to 2017 ones occurred in the first $2 \mathrm{~m}$ from the edge, with the number of captures gradually decreasing with increasing distance. This study provides information on the commuting patterns of $D$. rotundus in predominantly open cattle-ranching landscapes.

Los elementos lineales del paisaje son utilizados por muchas especies de murciélagos insectívoros como rutas de vuelo y zonas de forrajeo, además de brindarles protección contra factores ambientales y depredadores. Sin embargo, se conoce muy poco sobre el papel que estos elementos del paisaje juegan para especies no insectívoras. En este estudio, evaluamos el uso de los elementos lineales por el murciélago vampiro común (Desmodus rotundus) en un paisaje ganadero del estado de Tabasco, México. Seleccionamos 24 sitios de muestreo en 2014 y 24 sitios independientes en 2016-2017, todos adyacentes a tres tipos de elementos lineales del paisaje: bordes de bosque, cercos vivos y arroyos. Monitoreamos cada sitio durante dos noches no consecutivas entre febrero y abril de 2014 y cada dos meses de febrero de 2016 a junio de 2017. Colocamos 24 m (2014) o 12 m (2016 a 2017) de redes de niebla de manera perpendicular al elemento lineal a partir de su borde. Registramos la altura y distancia desde el borde para cada individuo capturado. En total capturamos 50 individuos de $D$. rotundus en 2014 y 58 individuos en 2016 a 2017. La altura promedio de vuelo fue de $77 \mathrm{~cm}$ para los datos de 2014 y de $69 \mathrm{~cm}$ para 2016 a 2017 . De acuerdo con nuestros resultados, los elementos lineales más utilizados fueron los bordes de bosque, seguidos de los cercos vivos y arroyos. En conjunto, el $52 \%$ de las capturas de 2014 y el $62 \%$ de las capturas de 2016 a 2017 se presentaron en los primeros 2 m a partir del borde, decreciendo gradualmente el número de capturas con el incremento en distancia. Este estudio permite conocer los patrones de movimiento de $D$. rotundus en paisajes ganaderos predominantemente abiertos.
\end{abstract}

Keywords: forest edges; hematophagous bat; live fences; movement patterns; streams.

๑ 2019 Asociación Mexicana de Mastozoología, www.mastozoologiamexicana.org

\section{Introduction}

Throughout the world, large tracts of original natural habitat have been replaced by mosaics of diverse habitats with different levels of human intervention, including forest fragments, areas with secondary vegetation, croplands and induced grasslands for cattle (Mena 2010). In many of these landscapes, there are continuous, structurally contrasting features with respect to adjacent habitats, which connect with each other and with different vegetation remnants (Gurrutxaga and Lozano 2008; García and Abad 2014). These types of linear features, present in heterogeneous landscapes, can be natural, such as rivers, canyons, riparian zones and vegetation strips (Limpens and Kapteyn 1991; Van Geert et al. 2010), or artificial, such as roads, railways and live fences (Van der Zanden et al. 2013).

For many non-flying land mammals, linear components function as corridors that facilitate movement between patches (Bennet 1998; Gurrutxaga and Lozano 2008; $\underline{\text { Huber }}$ et al. 2012). Similarly, some bats use linear landscape features as flight paths and foraging areas (Brandt et al. 2007; Loram et al. 2011). The linear features most used by bats are hedgerows, rivers and live fences, as well as other landscape components that have continuity such as forest edges and stone walls (Downs and Racey 2006; García and Santos 2014). In the case of insectivorous species, it has been suggested that linear features could be widely used because they offer greater food availability, protection against wind and predators, as well as spatial references that facilitate navigation (Limpens and Kapteyn 1991; Toffoli 2016). In some cases, the use of these spatial components may decrease the energetic cost of searching for foraging sites (Kusch et al. 2004; Barragán et al. 2010).

The structural characteristics of linear features could be related to the frequency with which they are used by different bat species. For example, it has been observed that the most commonly used live fences are those with the high- 
est heterogeneity levels, height and shrub cover (FuentesMontemayor et al. 2013). On the other hand, the intensity of use of these landscape components appears to be related to the flight patterns and echolocation of the different bat species. In particular, it has been observed that insectivorous species that emit intense, low frequency echolocation pulses (dominated by constant frequency components) tend to commute in open areas, while insectivorous species that produce weak, high frequency pulses (dominated by modulated frequency components) are those that use the landscape's linear features with greater intensity (Limpens and Kapteyn 1991; Bouhey et al. 2011).

The common vampire bat, Desmodus rotundus (Chiroptera, Phyllostomidae), is relatively abundant in cattleranching landscapes in Latin America (Escobar et al. 2015). This species, which feeds mainly on the blood of large herbivorous mammals, leaves its roost every night to search for prey during the periods of greatest darkness (Wimsatt 1969). Unlike insectivorous species, D. rotundus may depend on its vision to orient itself in space (Greenhall et al. 1983; Eklof 2003). Because its visual field is limited by its tendency to fly very close to the ground, $D$. rotundus is likely to rely heavily on spatial references to orient itself in the landscape. In addition, its limited ability to detect small or distant objects through echolocation (Joermann 1984; Rodriguez and Allendes 2016) would force it to fly close to objects that serve as a reference. According to this hypothesis, $D$. rotundus could be expected to fly very close to linear features in cattle-ranching landscapes dominated by open areas. To test this prediction, we evaluated the use of the different linear features of the landscape by $D$. rotundus in an agroecosystem of the municipality of Tacotalpa, in the state of Tabasco, Mexico. The objectives of the present study were: 1) to estimate the flight height and flight distance relative to linear landscape features by $D$. rotundus; and 2) to compare the use that $D$. rotundus makes of live fences, forest edges and small streams as flight routes. The results of this work allow us to assess the importance of linear landscape features for the spatial navigation of $D$. rotundus, as well as to identify sites where cattle could be more vulnerable to attacks by this predator.

\section{Materials and methods}

Study area. This study was conducted in the vicinity of the Xicoténcatl rural settlement, in the municipality of Tacotalpa, Tabasco. The region's characteristic climate is warm and humid, with year-round rainfall, average monthly temperatures ranging from 22 to $28^{\circ} \mathrm{C}$, and average annual rainfall of between 2,000 and $4,000 \mathrm{~mm}$ (INEGI 1998). In the low mountainous elevations, vegetation consists of fragments of medium-height semi-evergreen tropical forest and tall evergreen tropical forest with different levels of disturbance, while in the low, slightly undulating plains, induced grasslands predominate (Martínez et al. 2013). Large tracts of grassland are crossed by numerous live fences and some rivers, shallow valleys and streams. As in the entire munici- pality of Tacotalpa, the main economic activity is extensive cattle ranching (Secretaría de la Reforma Agraria 2012).

The main linear features present in the study area are live fences, streams, and forest edges. In this work, we consider forest edges as linear features, based on the classification of landscape components proposed by Downs and Racey (2006). In the study area, live fences represent the boundaries of the pastures, and are made up of small trees, known locally as cocoíte (Gliricidia sepium), linked with barbed wire. Initially, the cocoítes are planted as small trunks, but later branch again to form live trees arranged in a line. The region's streams are made up of shallow, conspicuous depressions that form in unstable terrain. Although the presence of flowing water is seasonal, they generally maintain small accumulations of water or mud in which hydrophilic grasses and forbs can grow. Some of these streams form small, relatively deep valleys bordered by steep slopes. Forest fragments are generally restricted to the steepest hills, so their edge is often delineated by the base of slopes and some stone walls. Due to deforestation, some forest edges have scattered trees, so the boundaries may be blurred.

Sampling design. In total, we selected 24 sampling sites, spaced at least $150 \mathrm{~m}$, at forest edges $(n=9)$ ), live fences ( $n$ $=10)$ and streams $(n=5)$. The sites were selected in such a way that they were not in the immediate vicinity (at least 60 $\mathrm{m}$ around) of other linear features that might interfere with the evaluated site. The first sampling stage was carried out between February 28 and April 29, 2014. A second set of data was collected between February 2016 and June 2017, at 24 sites different from those of the first sampling period. In this second stage, 12 sites were located in the El Paraíso ranch and 12 in the neighboring Poaná ejido; of the total number of sites, 19 corresponded to live fences, 4 to forest edges and 1 to a stream. The data from the second stage are derived from a parallel study carried out by our research group, whose objective depended on the collection of $D$. rotundus data throughout an annual cycle.

Data collection. Considering that $D$. rotundus reduces its activity during periods of greatest moonlight intensity (Flores-Crespo et al. 1972), we avoided sampling in the 10 days of most intense moonlight. We monitored each site for two non-consecutive nights per visit (one visit in 2014; six visits in 2016 to 2017). At each site, we placed a mist net perpendicular to the axis of the linear feature, positioning the first supporting pole as close as possible $(<30 \mathrm{~cm})$ to it. During the 2014 sampling, we placed 24 continuous $\mathrm{m}$ of net (combinations of 6 and $12 \mathrm{~m}$ nets aligned and adjacent, leaving no gaps between them), so the total sampling area covered from the vicinity of the linear feature to the interior of the open areas. We did not attempt to extend the nets beyond $24 \mathrm{~m}$ for two reasons: to avoid approaching adjacent linear features, especially in small pastures, and to reduce damage to nets caused by cattle. In addition, available information suggests that $D$. rotundus is rarely captured in open pastures (e. g., Medina et al. 2007). Because 
the sampling effort increased significantly (spatially and temporally) during the second stage, only $12 \mathrm{~m}$ of nets were placed at each site in 2016 to 2017 . In both stages, nets were placed at dusk and left open for seven hours (stage 2014) or five hours (stage 2016 to 2017). During the first stage, we made a total sampling effort of 8,064 m-net per hour, of which 3,024 m-net per hour was carried out at forest edges, 3,360 m-net per hour at live fences and 1,680 $\mathrm{m}$-net per hour at streams. During the second stage, a total sampling effort of 25,920 m-net per hour was made.

We used a flexometer to measure the height from the ground and distance from the linear feature of each individual found in the net. We identified the captured animals according to the criteria suggested by Medellín et al. (2008). To avoid counting newly released specimens twice, we fitted each individual with a plastic necklace containing small beads representing a color code. After obtaining routine morphometric data, the individuals were released at the same capture point.

Data analysis. Chi-square goodness of fit tests were used to assess whether $D$. rotundus tends to fly more frequently at a particular distance from linear landscape features, separately for each type (live fences, forest edges and streams) and together. For this, the number of captures was grouped according to the distance to the linear feature in $2 \mathrm{~m}$ intervals and compared with the number of captures that would be expected if the individuals were flying homogeneously in the landscape (equal capture frequency in each distance interval). This analysis was performed separately for the 2014 and 2016 to 2017 samples. To determine whether $D$. rotundus uses all three types of linear features with the same frequency, a non-parametric analysis of variance (KruskalWallis) was performed using the number of captures per site as the unit of analysis (Durán et al. 2005). Since only during the first sampling could we include an adequate number of sites corresponding to each type of linear feature, this last analysis was restricted to the 2014 sample.

\section{Results}

During the samplings carried out in 2014, we obtained a total of 50 captures corresponding to the species $D$. rotundus. Of the total number of individuals, 24 were caught at live fences, 20 at forest edges and six at streams. Only one individual was recaptured once. From the samplings conducted in 2016 and 2017, we obtained a total of 58 data on flight height and distance from the linear features. Results from both periods show that $D$. rotundus tends to fly very close to the ground (average height: $77 \mathrm{~cm}$ in 2014 and 69 $\mathrm{cm}$ in 2016 to 2017). Also, $88 \%$ of the 2014 captures and $82 \%$ of the 2016 to 2017 ones were obtained at heights equal to or less than $100 \mathrm{~cm}$. However, no individual was captured more than $160 \mathrm{~cm}$ above ground level.

We observed that $D$. rotundus shows a tendency to fly very close to the linear features of the landscape and to avoid open areas; $52 \%$ of the 2014 catches and $62 \%$ of the 2016 to 2017 ones were obtained in the first two meters, with the number of captures gradually decreasing as the distance from the linear feature increased (Figure 1). According to the Chi-square test, the use of the airspace covered by the nets adjacent to the linear features was not homogeneous (2014: $X^{2}=132.59, P<0.001 ; 2016$ to 2017: $\left.X^{2}=92.57, P<0.001\right)$.

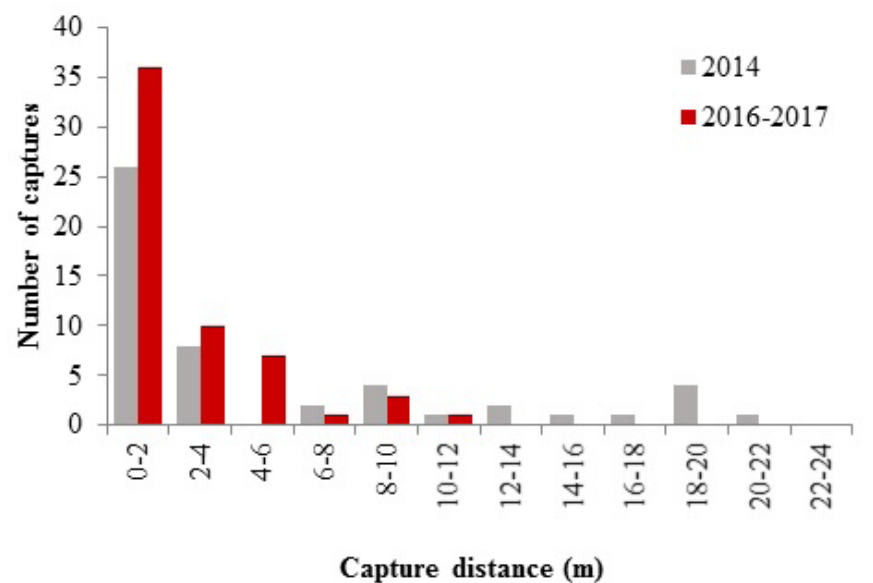

Figure 1. Number of $D$. rotundus individuals captured as a function of distance from linear landscape features (forest edges, live fences and streams) in cattle-ranching landscapes of Tacotalpa, Tabasco, for sampling periods 2014 and 2016-2017.

According to the Kruskal-Wallis test performed with the 2014 data, D. rotundus does not preferentially use one particular type of linear feature $(H=2.15, P=0.342)$, regardless of the capture distance. The average number of captures per site was 2.2 individuals for forest edges, 2.4 for live fences and 1.2 for streams. However, the flight pattern was different for each type of linear feature (Figure 2). At the forest edges, $\left(X^{2}=51.90, P<0.001\right), 80 \%$ of the captures were made in the first four meters, with the number of captures notably decreasing in the other distances. A similar pattern was observed in the streams and live fences (streams: $X^{2}=$ 8.62, $P=0.03$; live fences: $X^{2}=28.40, P<0.001$ ), although the percentage of captures in the first $4 \mathrm{~m}$ was lower than that of forest edges (Figure 2). Comparing the flight pattern in the three types of linear features, it can be observed that the tendency to fly near the linear features was more pronounced at the forest edges.

\section{Discussion}

Despite the extensive knowledge accumulated over several decades about the ecology of $D$. rotundus, this is the first study that describes its commuting patterns in agricultural landscapes. The flight height recorded in this study for $D$. rotundus is similar to that reported in a previous study on the attack behavior of this species, in which it was observed that individuals approached their prey at a height of between 50 and $150 \mathrm{~cm}$ (Greenhall et al. 1971). In the present study, the average flight height was around $70 \mathrm{~cm}$, indicating that vampires tend to fly at low altitudes while searching for prey or while commuting to and from their roosts.

It was observed that $D$. rotundus flies preferentially near linear landscape features and avoids open areas (grass- 


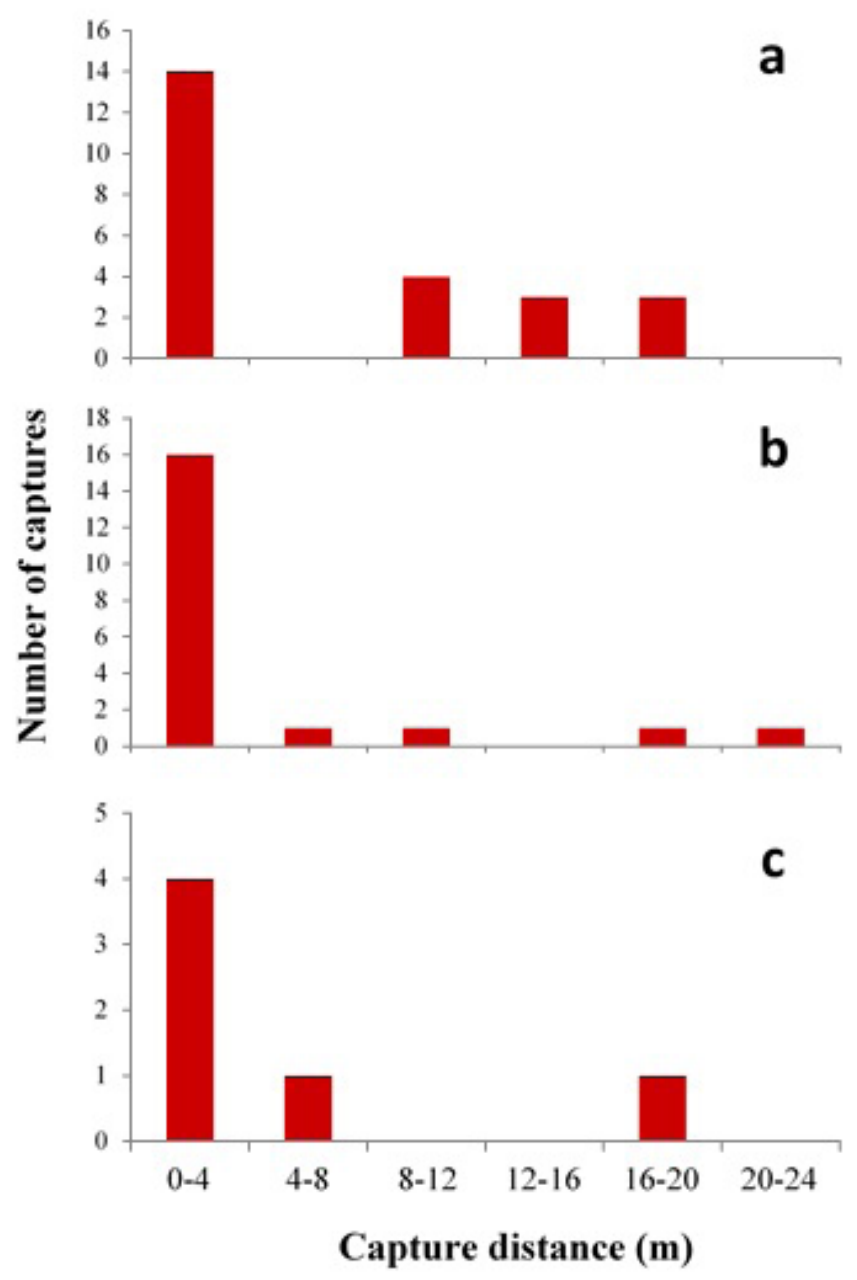

Figure 2. Number of $D$. rotundus individuals captured as a function of distance from three types of linear landscape features: a) live fences, b) forest edges, and c) streams, in cattle-ranching landscapes of Tacotalpa, Tabasco. Data correspond to the period 2014.

lands with scattered trees), as has been reported for several species of insectivorous bats (Lumsden and Bennett 2005; Downs and Racey 2006; Hein et al. 2009). Although there was no statistically significant preference for any type of linear feature, the greatest number of captures occurred at live fences and forest edges. The low level of stream use is similar to that observed in insectivorous species (Brandt et al. 2007), which could be because these sites increase the risk of predation due to the lack of tree cover (Russ and Montgomery 2002). However, this hypothesis has little support considering that $D$. rotundus avoids commuting during nights or hours with high levels of moonlight as a strategy to decrease the risk of predation (Flores-Crespo et al. 1972). Alternatively, lack of tree cover is likely to reduce the effectiveness of streams as spatial reference features in predominantly open landscapes.

Heavy rains and strong winds have been reported to decrease the foraging activity of $D$. rotundus (Wimsatt, 1969). Therefore, flying close to linear features may offer the common vampire bat protection against extreme environmental conditions, as has been suggested for some insectivorous species (Limpens and Kapteyn 1991; Brandt et al. 2007). This may explain, in part, why this species was observed more frequently using those linear features that had some degree of tree cover (live fences and forest edges).

Although $D$. rotundus has a moderately developed visual capacity (Greenhall et al. 1983; Eklof 2003), its low flight height may limit its field of vision. In addition, the short detection range by echolocation would prevent it from detecting objects at great distances, which in turn would make commuting and orientation difficult in open areas (Joermann 1984). For this reason, we suggest that $D$. rotundus shows a greater tendency to fly near linear landscape features because they act as reference points for spatial orientation (for a discussion on the role of linear features in insectivorous species, see Limpens and Kapteyn 1991).

One factor that may influence the usefulness of linear landscape components as reference points for the spatial orientation of $D$. rotundus is the level of contrast between the linear feature and the open areas. If these features are well defined in space, they could facilitate the commuting of individuals along the landscape (Fuentes-Montemayor et al. 2013). This would explain the low level of use observed in streams, which had a more diffuse structure relative to the surrounding pastures, while forest edges and living fences were generally well defined linearly.

It has been suggested that food abundance is a factor promoting the use of linear features by insectivorous bats (Verboom and Huitema 1997; Lumsden and Bennett 2005; Fuentes-Montemayor et al. 2013; Kalda 2015). This theory, however, has not been explored in non-insectivorous species, including $D$. rotundus. In a study conducted in a cattle-ranching area of Colombia, it was found that, during the hottest time of the year, cattle explore areas with tree cover in search of a better food supply during the night and part of the early morning (Polania 2012). Therefore, there is a possibility that, at least in some regions and at some times of the year, D. rotundus would prefer to commute in the immediate vicinity of wooded areas because they have greater prey availability.

The flight patterns observed in this study suggest that the most vulnerable prey to hematophagous bat attacks would be those resting at night near linear landscape features. This would explain why domestic animals maintained near wooded areas and $D$. rotundus roosting sites are most often bitten by vampire bats (Novaes et al. 2010; Costa and Esbérard 2011; Hernández-Pérez et al. 2019). In addition, this hypothesis is supported by the results of various experimental studies which documented that $D$. rotundus has a short detection range of objects (including experimental "prey") through the senses of echolocation (Joermann 1984), smell (Bahlman et al. 2007), thermoperception (Kürten et al. 1982), and passive hearing of sounds emitted by prey (Schmidt et al. 1991; Heffner et al. 2013). The role of sight is more uncertain (Greenhall et al. 1983; Eklof 2003), although the visual detection of prey by $D$. rotundus can be expected to decrease with increasing distance from its flight paths. An additional reason that might explain the preference of $D$. rotundus for linear landscape features (especially wooded ones) is the search for levels of dark- 
ness that maximize its ability to visually detect prey, while reducing the likelihood of being detected by them. The three hypotheses (need for spatial references, maximization of visual function in conditions of maximum darkness and minimization of the risk of being detected by prey) are not mutually exclusive and could occur simultaneously.

The flight patterns reported in this study for the common vampire bat are consistent in space and time. Considering that the number of recorded individuals decreases gradually as the distance from the linear features of the landscape increases, we can suggest (with a high level of confidence) that $D$. rotundus prefers to fly close to the linear features in predominantly open landscapes. The results reported herein have strong implications for livestock management in tropical regions, considering that the production animals most vulnerable to attacks by $D$. rotundus (and therefore most at risk of being infected with rabies) are those that rest near linear landscape features.

\section{Acknowledgements}

We acknowledge the owners of all ranches and properties where the study took place. In particular, we are indebted to the owners, workers and cowboys of El Paraíso and Poaná ranches for providing help and permission to conduct our study. We are grateful to the colleagues, students and volunteers that provided field assistance during the seasons 2014 and 2016 to 2017, with special thanks to Jorge D. Gutiérrez-Hernández and Samuel Oporto-Peregrino. The associate editor and two anonymous reviewers made substantial contributions to improve the manuscript. Financial support was provided by UJAT-PTC-173 (CLAVE PROMEP/103.5/13/7044) and UJAT-2014-IA-10.

\section{Literature cited}

BAHLMAN, J. WM., AND D. A. KELt. 2007. Use of olfaction during prey location by the common vampire bat (Desmodus rotundus). Biotropica 39:147-149.

Barragán, F., C. Lorenzo, A. Morón, M. A. Briones-Salas, and S. López. 2010. Bat and rodent diversity in a fragmented landscape on the Isthmus of Tehuantepec, Oaxaca, México. Tropical Conservation Science 3:1-16.

BENNET, A. F. 1998. Linkages in the landscape: the role of corridors and connectivity in wildlife conservation. IUCN, Gland, Suiza y Cambridge, U.K.

Bernatd, E., and M. B. Fenton. 2007. Bats in a fragmented landscape: species composition, diversity and habitat interactions in savannas of Santarém, Central Amazonia, Brazil. Biological Conservation 134:332-343.

Brandt, G., L. Blows, D. Linton, N. Paling, and C. Prescott. 2007. Habitat associations of British bat species on lowland farmland within the Upper Thames catchment area. Centre for Wildlife Assessment \& Conservation E-Journal 1:10-19.

Bouhey, K. L., I. R. Lake, K. A. Haysom, and P. M. Dolman. 2011. Improving the biodiversity benefits of hedgerows: How physical characteristics and the proximity of foraging habitat affect the use of linear features by bats. Biological Conservation 144:1790- 1798.
Costa, L. M., AND C. E. L. Esbérard. 2011. Desmodus rotundus (Mammalia: Chiroptera) on the southern coast of Rio de Janeiro state, Brazil. Brazilian Journal of Biology 71:739-746.

Downs, C. N., AND P. A. RaCEY. 2006. The use by bats of habitat features in mixed farmland in Scotland. Acta Chiropterologica 8:169-185.

EKLÖF, J. 2003. Vision in echolocating bats. Göteborg University, Department of Zoology. Thesis Zoology Department, Göteborg University, Germany.

Escobar, L. E., A. T. Peterson, M. Favi, V. Yung, and G. Medina-Vogel. 2015. Bat-borne rabies in Latin America. Revista do Instituto de Medicina Tropical de São Paulo 57:63-72.

Flores-Crespo, R., S. B. Linhart, R. J. Burns, and G. Clay Mitchell. 1972. Foraging behavior of the common vampire bat related to moonlight. Journal of Mammalogy 53:366-368.

Fuentes-Montemayor, E., D. Goulson, L. Cavin, M. J. Wallace, And J. K. PARK. 2013. Fragmented woodlands in agricultural landscapes: the influence of woodland character and landscape context on bats and their insect prey. Agriculture, Ecosystems and Environment 172:6-15.

García, F., AND J. Abad. 2014. Los corredores ecológicos y su importancia ambiental: Propuestas de actuación para fomentar la permeabilidad y conectividad aplicadas al entorno del río Cardeña (Ávila y Segovia). Observatorio medioambiental 17:253-298.

GarCía, J., AND A. Santos. 2014. Efectos de la estructura del paisaje y de la vegetación en la diversidad de murciélagos filostómidos (Chiroptera: Phyllostomidae) de Oaxaca, México. Revista de Biología Tropical 62:217-240.

Greenhall, A. M., G. Joermann, and U. Schmidt. 1983. Desmodus rotundus. Mammalian Species 202:1-6.

Greenhall, A. M., U. SChmidT, AND W. Lopez-Forment. 1971. Attacking behavior of the vampire bat, Desmodus rotundus, under field conditions in Mexico. Biotropica 3:136-141.

Gurrutxaga, S. M., And P. J. Lozano. 2008. Ecología del paisaje: un marco para el estudio integrado de la dinámica territorial y su incidencia en la vida silvestre. Estudios geográficos 265:519-543.

Heffner, S. R., G. Koay, and E. H. Heffner. 2013. Hearing in American leaf-nosed bats. IV: The Common vampire bat, Desmodus rotundus. Hearing Research 296:42-50.

Hein, D. C., B. S. CASTLEBERRY, AND V. K. Miller. 2009. Site-occupancy of bats in relation to forested corridors. Forest Ecology and Management 257:1200-1207.

Hernández-Pérez, E. L., G. Castillo-Vela, G. García-Marmolejo, M. Sanvicente-López, and R. Reyna-Hurtado. 2019. Wild pig (Sus scrofa) as prey of the common vampire bat (Desmodus rotundus). Therya 10:195-199.

Huber, P., F. Shilling, J. Thorne, and S. Greco. 2012. Municipal and regional habitat connectivity planning. Landscape and Urban Planning 105:15-26.

Instituto Nacional de Estadistica y Geografía. 1998. Cuaderno Estadístico Municipal de Tacotalpa. Estado de Tabasco. Edición 1998. Instituto Nacional de Estadística Geografía e Informática. Gobierno del H. Ayuntamiento Constitucional de Tacotalpa. Tacotalpa, México.

JoERMANN, G. 1984. Recognition of spatial parameters by echolocation in the vampire bat, Desmodus rotundus. Journal of Comparative Physiology 155:67-74. 
Kalda, O., R. Kalda, And J. LilRA. 2015. Multi-scale ecology of insectivorous bats in agricultural landscapes. Agriculture, Ecosystems and Environment 199:105-113.

KüRTEN, L., AND U. SCHMIDT. 1982. Thermoperception in the common vampire bat (Desmodus rotundus). Journal of Comparative Physiology 146:223-228.

Kusch, J., C. Weber, S. Idelberger, And T. КоOB. 2004. Foraging habitat preferences of bats in relation to food supply and spatial vegetation structures in a western European low mountain range forest. Folia Zoologica 53:113-128.

Limpens, H. J. G. A., AND K. KaPteyn. 1991. Bats, their behavior and linear landscape elements. Myotis 29:39-48.

Loram, A., P. Warren, K. Thompson, and K. Gaston. 2011. Urban domestic gardens: the effects of human interventions on garden composition. Environmental Management 48:808-824.

LumSDEN, F. L., AND F. A. BenNetT. 2005. Scattered trees in rural landscapes: foraging habitat for insectivorous bats in southeastern Australia. Biological Conservation 122:205-222.

Martínez-Encino, C., G. Villanueva-López, and F. Casanova-Lugo. 2013. Densidad y composición de árboles dispersos en potreros en la sierra de Tabasco, México. Agrociencia 47:483-496.

Medellin, R. A., T. H. Arita, and H. O. Sánchez. 2008. Identificación de los murciélagos de México. Clave de campo. Segunda edición. Instituto de ecología UNAM. Ciudad de México, México.

Medina, A., C. A. Harvey, D. S. Merlo, S. Vilchez, and B. Hernández. 2007. Bat diversity and movement in an agricultural landscape in Matiguás, Nicaragua. Biotropica 39:120-128.

MenA, J. L. 2010. Respuestas de los murciélagos a la fragmentación del bosque en Pozuzo, Perú. Revista Peruana de Biología 17:277-284.

Novaes, G. M., M. A. M. Vieira, N. Lewis, C. A. Goncalves, and F. V. NogUeIRA. 2010. Landscape risk factors for attacks of vampire bats on cattle in Sao Paulo, Brazil. Preventive Veterinary Medicine 93:139-146.

Polania Ortiz, Y. E. 2012. Movimiento de vacunos en un paisaje arbolado y su relación con el gasto de energía. Universidad de Tolima, Facultad De Medicina Veterinaria y Zootecnia.

Rodríguez, S. A., AND J. L. Allendes. 2016. Echolocation calls of freeflying common vampire bats Desmodus rotundus (Chiroptera: Phyllostomidae) in Chile. Bioacustics 26:153-160.

Russ, J. M., AND W. I. Montgomery. 2002. Habitat associations of bats in Northern Ireland: implications for conservation. Biological Conservation 108:49-58.

Secretaria de la Reforma Agraria. 2012. Cuaderno de alternativas de desarrollo y retos del núcleo agrario: ejido Xicotencatl. Tacotalpa, México.

Schmidt, U., P. Schlegel, H. Schweizer, and G. Neuweiler. 1991. Audition in vampire bats, Desmodus rotundus. Journal of Comparative Physiology 168:45-51.

Toffoli, R. 2016. The importance of linear landscape elements for bats in a farmland area: The influence of height on activity. Journal of Ecology 9:1.

Van der Zandena, H. E., H. P. Verburga, and A. C. Mucher. 2013. Modelling the spatial distribution of linear landscape elements in Europe. Ecological Indicators 27:125-136.

Van geert, A., F. Van Rossum y L. Triest. 2010. Do linear landscape elements in farmland act as biological corridors for pollen dispersal? Journal of Ecology 98:178-187.
Verboom, B., And H. Huitema. 1997. The importance of linear landscape elements for the pipistrelle Pipistrellus pipistrellus and the serotine bat Eptesicus serotinus. Landscape Ecology 12:117-125.

Wimsatt, W. A. 1969. Transient behavior, nocturnal activity patterns, and feeding efficiency of vampire bats (Desmodus rotundus) under natural conditions. Journal of Mammalogy 50:233-244.

Associated editor: Lazaro Guevara

Submitted: Julio 4, 2019; Reviewed: August 25, 2019;

Accepted:September 9, 2019; Published on line:September 23, 2019. 